\title{
DAMPAK IMPLEMENTASI E-PROCUREMENT PADA SUPPLY CHAIN PERFORMANCE
}

Angelita Nauli Panggabean - 2301950881 - LB21

E-Business Strategy and Implementation

\begin{abstract}
Abstrak
Perubahan teknologi yang diiringi oleh perubahan pasar yang pesat, telah membuat perusahaan semakin sulit dalam mengembangkam bisnisnya di masa depan. Kini, banyak organisasi yang bergeser ke $e$-procurement sebagai fungsi pendukung rantai pasokan terintegrasi untuk mencapai tujuan bisnis strategis. E-procurement atau pengadaan elektronik ini telah memungkinkan untuk lebih banyak fleksibilitas dalam menanggapi perubahan pasar dan meningkatkan performa rantai pasokan perusahaan. Tujuan dari karya tulis ini adalah untuk mengetahui dampak dari implementasi e-procurement pada peforma rantai pasokan perusahaan. Metode yang digunakan karya tulis ini adalah dengan mengumpulkan dan mempelajari jurnal-jurnal, baik jurnal nasional maupun internasional yang didapatkan dari berbagai sumber melalui internet. Dari jurnal-jurnal tersebut, dapat disimpulkan bahwa implementasi e-procurement memiliki pengaruh yang signifikan terhadap supply chain performance.
\end{abstract}

Kata Kunci: E-Procurement, Supply Chain Performance

\section{Pendahuluan}

Di tengah perubahan teknologi serta diiringi dengan persaingan yang ketat antar perusahaan, telah menjadi tantangan bagi perusahaan dalam mengembangkan bisnisnya di masa depan (Sudrajat et al., 2019). Dengan begitu, supply chain atau rantai pasokan perlu dipastikan efisiensinya dengan menerapkan strategi yang tepat. Kebutuhan perbaikan dalam hal efisiensi dan kualitas telah megarahkan logistik untuk mengadopsi solusi dan strategi baru yang mampu memberikan fleksibilitas kepada pembeli dalam memilih pemasok dan sumber produk (Chibani et al., 2018). Perkembangan teknologi yang pesat saat ini, mengharuskan perusahaan untuk memberikan layanan berbasis teknologi dengan ide-ide inovatif demi meningkatkan kinerja perusahaan (Ngeno \& Kinoti, 2017). Oleh karena itu, terbukti bahwa fokus banyak organisasi telah bergeser ke $e$-procurement sebagai fungsi pendukung rantai pasokan terintegrasi untuk mencapai tujuan bisnis strategis, seperti efisiensi operasional, keberlanjutan, dan profibilitas (Mabeifam et al., 2017). Penurunan ekonomi secara global pun, mempengaruhi adanya perubahan dalam 
dinamika bisnis ini. Pengadaan merupakan kegiatan bisnis yang krusial dan mahal bagi setiap organisasi yang disebabkan oleh (Mabeifam et al., 2017):

- Pengadaan yang dilakukan secara tradisional adalah kegiatan yang menghabiskan lebih banyak waktu untuk nilai yang tidak bernilai tambah.

- Dalam pengadaan tradisional, memungkinkan terjadi pembelian yang tidak sesuai dengan rencana dengan harga yang lebih tinggi.

E-procurement atau pengadaan elektronik telah memungkinkan untuk lebih banyak fleksibilitas dalam menanggapi perubahan pasar yang bergejolak. Pesatnya perkembangan pasar elektronik telah memberikan dampak kepada pemasok dan pembeli untuk menjual dan membeli produk secara online. Kegiatan dalam pasar elektronik ini umumnya mengacu pada manajemen rantai pasokan elektronik. Dalam proses supply chain, e-procurement memberikan keutungan kepada perusahaan yang mengadopsinya. Proses pengadaan elektronik (e-procurement) melibatkan barang atau jasa dengan biaya terbaik untuk memenuhi kebutuhan pembeli dalam hal kualitas dan kuantitas, waktu, serta lokasi. Proses pembelian tradisional memiliki inefisiensi dan waktu yang lama dalam memproses pesanan, baik secara internal maupun eksternal. Dengan demikian, e-procurement ini sangat mendukung dan juga meningkatkan performa rantai pasokan serta strategi logistik. Selain itu, e-procurement pun memberikan dampak positif dalam meningkatkan produktivitas, pengurangan lead time, serta kesalahan yang lebih sedikit dalam manajemen persediaan, sehingga e-procurement dapat mengubah cara bisnis dijalankan (Ngeno \& Kinoti, 2017). Oleh karena itu, penulis ingin mengetahui apakah terdapat pengaruh antara mengimplementasikan e-procurement terhadap supply chain performance.

\section{Tinjauan Pustaka}

\section{E-Procurement}

Procurement atau pengeadaan merupakan proses mendapatkan barang atau jasa dari sumber eksternal (Mabeifam et al., 2017). Dalam prosesnya, perlu diperhatikan bahwa barang atau jasa harus sesuai dan diperoleh dengan biaya terbaik untuk memenuhi kebutuhan pembeli dalam hal kualitas, kuantitas, waktu, dan lokasi. Untuk meningkatkan proses pengadaan, perusahaan 
menggunakan inovasi pengadaan elektronik atau e-procurement. Menurut Conolly dan Olson (2010), e-procurement ini merupakan salah satu pendorong perubahan terbesar di industri mana pun. Banyak bisnis yang mulai mengadopsi teknologi karena faktor untuk mengurangi biaya serta meningkatkan kualitas layanan pelanggan. E-procurement memungkinkan perusahaan untuk mendesentralisasikan proses pengadaan operasional serta memusatkan proses pengadaan strategis, sehingga meningkatkan transparansi rantai pasokan. Berdasarkan (Pattanayak \& Punyatoya, 2020), e-procurement (electronic procurement) atau pengadaan elektronik adalah praktik pembelian bisnis ke bisnis yang memanfaatkan perdagangan elektronik untuk mengidentifikasi sumber pasokan potensial, untuk membeli barang dan jasa, untuk mentransfer pembayaran dan untuk berinteraksi dengan pemasok. Sistem pengadaan elektronik ini berfous pada pempat fungsi, antara lain e-sourcing, e-negotiation, e-design, dan e-valuation (Pattanayak \& Punyatoya, 2020). Menurut (Naoum \& Egbu, 2016), pengadaan elektronik membantu meningkatkan kolaborasi antara pemasok dan pembeli, mengurangi kebutuhan pribadi, mengurangi biaya transaksi, menerima lebih banyak tawaran dari berbagai calon penawar, meningkatkan koordinasi, siklus pengadaan yang lebih pendek, meningkatkan jejak audit, dan transparansi yang lebih besar. Kolaborasi antara pembeli dan penjual ini secara positif mempengaruhi inovai dan juga kinerja organisasi. Penelitian (Pattanayak \& Punyatoya, 2020), menyebutkan bahwa e-procurement dapat membantu dalam meningkatkan kualitas, waktu pemrosesan, dan penghematan biaya. Sistem $e$ procurement dapat meningkatkan efektivitas proses operasi dan transparansi rantai pasok (Ngeno \& Kinoti, 2017). Penelitian lainnya, (Pattanayak \& Punyatoya, 2020), juga menyebutkan bahwa e-procurement membantu dalam penghematan biaya keseluruhan dalam proses pembelian dan memfasilitasi transparansi rantai pasokan dalam hal spesifikasi produk, harga, detail kontrak, dan keputusan yang lebih cepat untuk masalah melalui informasi waktu nyata.

\section{Supply Chain Performance}

Supply chain atau rantai pasokan didefinisikan sebagai jaringan organisasi yang terlibar, melalui hubungan hulu dan hilir dalam berbagai proses dan aktivitas yang menghasilkan nilai dalam bentuk barang atau jasa di tangan pelanggan akhir (Mabeifam et al., 2017). Supply chain performance mengacu pada hasil berwujud (biaya dan kualitas) dan tidak berwujud (pemanfaatan kapasitas dan pemanfaatan sumber daya) melalui penggunaan SCM yang efektif (Pattanayak \& Punyatoya, 2020). Kinerja perusahaan yang digerakkan oleh rantai pasokan dibedakan menjadi: 
kinerja sumber daya, kinerja keluaran, dan kinerja fleksibilitas. Kinerja sumber daya merupakan nilai tambah dalam hal mencapai efisiensi; kinerja keluaran merupakan nilai tambah dalam hal kemampuan perusahaan untuk menyediakan layanan; sedangkan kinerja fleksibilitas merupakan nilai tambah dalam hal kemampuan perusahaan untuk merespons perubahan. Pada organisasi yang berbasis proyek, mengukur supply chain performance sulit dilakukan karena banyaknya aktor yang terlibat dan potensi ketidakpastian dalam rantai pasokan.

\section{Metode}

Karya tulis ini dibuat dengan metode tinjauan literatur, dimana penulis mengumpulkan dan mempelajari jurnal-jurnal dan sumber tertulis lainnya. Jurnal tersebut terdiri dari jurnal mengenai e-procurement dan supply chain yang didapatkan dari berbagai platform di internet, seperti Google Scholar, Science Direct, dan ResearchGate dengan tahun publikasi dari tahun 2016 hingga 2021. Jurnal yang didapat dipelajari dan dipahami oleh penulis untuk mencapai kesimpulan karya tulis.

\section{Kesimpulan}

Perkembangan teknologi telah membawa kemudahan pada layanan sehingga banyak perusahaan yang mengadopsi e-procurement sebagai pendukung rantai pasokan untuk mampu beradaptasi dengan perubahan pasar serta untuk mencapai tujuan binis, seperti efisiensi operasional, keberlanjutan, dan profitabilitas (Mabeifam et al., 2017). Banyak perusahaan yang mengadopsi e-procurement karena kemampuannya untuk merampingkan jaringan rantai pasokan. Munculnya e-procurement telah menciptakan profil yang lebih tinggi untuk manajemen pasokan serta meningkatkan visibilitas ke manajemen puncak perusahaan. Dengan mengadopsi teknolog ini, telah mempengaruhi kinerja organisasi, baik secara langsung maupun tidak langsung (Pattanayak \& Punyatoya, 2020). E-procurement ini membawa transparansi dan efektivitas dalam rantai pasokan dan memberikan kontribusi yang signifikan terhadap peforma rantai pasokan. Selain itu, e-procurement pun memungkinkan perusahaan untuk mengukur dan memantau pesanan, seperti waktu pemrosesan, waktu pesanan dikirim, dan status saat ini (Mabeifam et al., 2017). Oleh karena itu, mengimplementasikan e-procurement pada perusahaan memainkan peran penting dan akan memberikan dampak pada peningkatan peforma rantai pasokan (Pattanayak \& Punyatoya, 2020). 


\section{Reference:}

Chibani, A., Delorme, X., Dolgui, A., \& Pierreval, H. (2018). Dynamic optimisation for highly agile supply chains in e-procurement context. International Journal of Production Research, 56(17), 5904-5929. https://doi.org/10.1080/00207543.2018.1458164

Mabeifam, M., Arora, R., K., A., \& Namulo, L. (2017). Employee Adoption of E-Procurement and its Implication on Supply Chain in Developing Countries. International Journal of Computer Applications, 171(9), 11-15. https://doi.org/10.5120/ijca2017914850

Naoum, S. G., \& Egbu, C. (2016). Modern Selection Criteria for Procurement Methods in Construction: A State-of-the-art Literature Review and A Survey. International Journal of Managing Projects in Business, 9(2), 309-336. https://doi.org/10.1108/IJMPB-09-20150094

Ngeno, K., \& Kinoti, J. (2017). Effect of E-Procurement on Effective Supply Chain Management Process in Energy Sector in Kenya. In International Journal of Supply Chain Management (Vol. 2, Issue 4). www.iprjb.org

Pattanayak, D., \& Punyatoya, P. (2020). Effect of Supply Chain Technology Internalization and E-procurement on Supply Chain Performance. Business Process Management Journal, 26(6), 1425-1442. https://doi.org/10.1108/BPMJ-04-2019-0150

Sudrajat, D., Saroso, H., Grace Herlina, M., \& Hida Syahchari, D. (2019). The Role of Sensing Capability in Improving Financial Performance of Logistics Service Firms. International Journal of Innovation, Creativity and Change, 10(9). www.ijicc.net 